Johann Baumgärtner 1

Markus Bieri 2

Giuseppe Buffoni 3

Gianni Gilioli 4

Hiremagalur Gopalan 5

Jürgen Greiling 1

Getachew Tikubet 1

Ingeborg Van Schayk 1

\section{Human health improvement in Sub-Saharan Africa through integrated management of arthropod transmitted diseases and natural resources}

\author{
Mejoramiento de la salud humana en África \\ al sur del Sahara mediante el manejo integrado \\ de enfermedades transmitidas por artrópodos \\ y el manejo de recursos naturales
}

1 International Centre of Insect Physiology and Ecology (ICIPE), P.O. Box 30772, Nairobi, Kenya. 2 Swiss Federal Institute of Technology (ETH), 8092 Zurich, Switzerland. 3 Italian National Agency for New Technology, Energy, and the Environment (ENEA), C.P. 31619100

La Spezia, Italy.

4 Dipartimento di Agrochimica e Agrobiologia, Università degli Studi di Reggio Calabria. Piazza S. Francesco di Sales 4, 89061 Gallina di Reggio Calabria. 5 United Nations Environment Program (UNEP), P.O. Box 30552, Nairobi, Kenya.

\begin{abstract}
A concept of an ecosystem approach to human health improvement in Sub-Saharan Africa is presented here. Three factors mainly affect the physical condition of the human body: the abiotic environment, vector-transmitted diseases, and natural resources. Our concept relies on ecological principles embedded in a social context and identifies three sets of subsystems for study and management: human disease subsystems, natural resource subsystems, and decisionsupport subsystems. To control human diseases and to secure food from resource subsystems including livestock or crops, integrated preventive approaches are preferred over exclusively curative and sectorial approaches. Environmental sustainability - the basis for managing matter and water flows - contributes to a healthy human environment and constitutes the basis for social sustainability. For planning and implementation of the human health improvement scheme, participatory decision-support subsystems adapted to the local conditions need to be designed through institutional arrangements. The applicability of this scheme is demonstrated in urban and rural Ethiopia.
\end{abstract}

Key words Ecosystem; Natural Resources; Nutrition; Vector Control; Public Health

Resumen Se presenta un concepto, basado en el ecosistema, para el mejoramiento de la salud humana en la región del África al sur del Sahara. Las condiciones físicas del cuerpo humano estan afectadas por tres factores: factores ambientales abióticos, enfermedades transmitidas por vectores, y por los recursos naturales. Este concepto se basa en princípios ecológicos dentro de un contexto social, e identifica tres series de subsistemas para estudio y manejo: subsistemas de enfermedades humanas, subsistemas de recursos naturales y subsistemas participativos de toma de decisiones. En el manejo de enfermedades humanas, así como en el manejo de recursos tales como ganadería o agricultura, se da prioridad a programas preventivos de manejo integrado. El concepto de sostenibilidad ambiental - base para el manejo de materia y de aguas - contribuye a un medio ambiente favorable para las condiciones de vida del ser humano, y es la base de la sostenibilidad social. Para la planificación y la ejecución del esquema de mejoramiento de la salud humana, se necesita un sistema participativo de toma de decisiones, adaptado a las condiciones locales y desarrollado en base a acuerdos institucionales. La aplicabilidad de este esquema es demostrada en la zona rural y urbana de Etiopia.

Palabras clave Ecosistemas; Recursos Naturales; Nutrición; Control de Vectores; Salud Pública 
"Human beings are at the center of concerns for sustainable development. They are entitled to a healthy and productive life in harmony with nature" (Rio Declaration: Principle 1, UNCED, Rio de Janeiro, Brazil, 1992)

\section{Introduction}

The World Health Organization (WHO, 1995) defines human health as a state of complete physical, mental, and social well-being and not merely as the absence of disease or infirmity. To address this comprehensive concept is a major challenge but undoubtedly goes beyond the scope of this paper. Here we focus on those aspects of human health that concern the physical condition of the human body, considering that physical well-being contributes to mental and social well-being. In due course, when normative sciences are applied to issues of human health and inherent values are added to the systems to be managed (Fitzsimmons, 1999), we look forward to broadening our concept in accordance with the above-described comprehensive definition of human health.

Global trends in human health improvements are positive. In Sub-Saharan Africa, however, progress has been slow and life expectancy still lags some 25 years behind that of the wealthiest nations (WRI, 1998). Taken into account both premature death and disability, nearly $90 \%$ of the global disease burden occurs in developing countries (WRI, 1998). In SubSaharan Africa, morbidity rates show a disease burden that doubles the global average. Protection against and treatment of diseases is often beyond reach of the poor, and the increasing effects of manmade and natural disasters will further exacerbate poverty and disease.

Management of the environment is a promising strategy to improve human health (WRI, 1998). Systematic and coordinated procedures, developed together with the communities involved, will facilitate the design and implementation of management schemes in Africa. A holistic approach that is based on ecological principles as well as on the participation of the community and its relevant institutions in the design, implementation, and evaluation of management schemes is promising with respect to improving human health and, moreover, alleviating poverty in developing countries.

This paper presents a conceptual framework for the design and implementation of a community-driven, comprehensive health and integrated resource management scheme for improving human health in Sub-Saharan Africa. The applicability of the concepts is being tested in urban and rural environments in Ethiopia.

\section{Human health and the environment}

The components of the human environment, regarded as everything that is external to the individual human host (Last \& Abramson, 1995), can be divided into: atmospheric, aquatic, and terrestrial components, encompassing both abiotic and biotic elements (Figure 1).

Among the biotic elements, the malarial parasite is the main cause of morbidity and mortality in the African region. Ninety-three percent of the 550 million people living on this continent are at risk. Over $90 \%$ of the annual global 1.4-2.6 million deaths are reported from Africa (WHO, 1995). A second vector, the tsetse fly (Glossinidae), transmits human trypanosomiasis, or sleeping sickness. With an estimated 300,000 cases per year, the disease has returned to its epidemic levels of the 1930s (Saini et al., 1999b). Diseases transmitted by hard ticks (Ixodidae) and tick paralysis (Kettle, 1995) also hamper the continent.

Disease incidence is directly related to nutrition: approximately $32 \%$ of the disease burden in Africa can be attributed to proteinenergy malnutrition. This refers to the consequences of the combination of an inadequate intake of protein and energy as well as micronutrients, such as vitamin A, iron, and iodine. Fifty-five percent of all child deaths in developing countries are associated with malnutrition. This includes deaths from diarrhea (19\%), acute respiratory infections (19\%), perinatal causes (18\%), measles $(7 \%)$, malaria $(5 \%)$, and other causes (32\%). In Africa, $10 \%$ of the disease burden is caused by inadequate drinking water, sanitation, and hygiene. Degraded households increase the incidence of airborne diseases and diarrhea (WRI, 1998). Poor environmental conditions increase diseases such as tuberculosis, acute respiratory track infections, and diarrhea.

Livestock and crops are the main sources of food. Factors affecting these sources have an immediate impact on human health. In livestock, tsetse fly transmitted trypanosome parasites cause debilitating and often fatal livestock diseases (Saini et al., 1999b). In cattle, losses amount to an estimated 3 million deaths annually, mainly of young stock. Sick animals produce lower milk and meat yields, and reproduce less. With nearly 50 million head of cattle $-94 \%$ of the continent's total - distributed at 
the fringes of the tsetse belt, the direct annual monetary loss is estimated at US\$ 0.6 to 1.2 billion. Hard ticks (Ixodidae) transmit protozoan (theileriosis and babesiosis) as well as rickettsial diseases and predispose animals to secondary infections. In eastern and central Africa alone, the damage caused by theileriosis is estimated at US\$ 168 million annually, including an estimated mortality of 1.1 million cattle (Mukhebi, 1992). Inadequate feed supply has an additional impact on animal health.

In agriculture, crop production is constrained by abiotic factors and pests (Yudelman et al., 1998). Research on cotton (Baumgärtner et al., 1986), cassava (Gutierrez et al., 1988), rice (Baumgärtner et al., 1989), cowpeas (Tamò \& Baumgärtner, 1993; Tamò et al., 1993), and maize (Bonato et al., 1999) demonstrates multiple stresses on yields of some crops. For example, losses in maize due to stem borers are substantial (Cardwell et al., 1997) and range from 0 to $100 \%$, (Gebre Amlak et al., 1989). Lack of water, nitrogen, and phosphorous are among the main direct and indirect constraints (Bonato et al., 1999). Climatic variability, particularly in semi-arid areas, and limited use of fertilizers and livestock-mediated nutrient transfers from pastureland to croplands interfere with forage crops. In maize, 10-15\% losses due to drought and nitrogen stress have been reported from many countries, while $90 \%$ yield reduction due to low nitrogen levels have been observed in Malawi (Zambesi \& Mwambula, 1996).

The definition of the human environment as described here facilitates categorization of health constraints over large spatio-temporal scales. The characterization of elements such as the abiotic environment, arthropod-transmitted diseases, and malnutrition enables identification of relevant environmental factors suitable for policy-making (Conway, 1984). The design of management schemes adapted to local conditions, however, also needs to take into account the social environment, the interaction between its actors, and the mutual effects between social processes and the environment. An ecosystem approach is more appropriate and more comprehensive in this respect.

\section{An ecosystem approach to human health improvement}

People do not live in isolation. They are actors in highly structured ecological systems. The hierarchical organization of nature has become a basic philosophical presumption in ecology (Naveh \& Liebermann, 1994). Accordingly, the
Figure 1

The human health improvement system composed of humans and their environment, separated into atmospheric, terrestrial, and aquatic components.

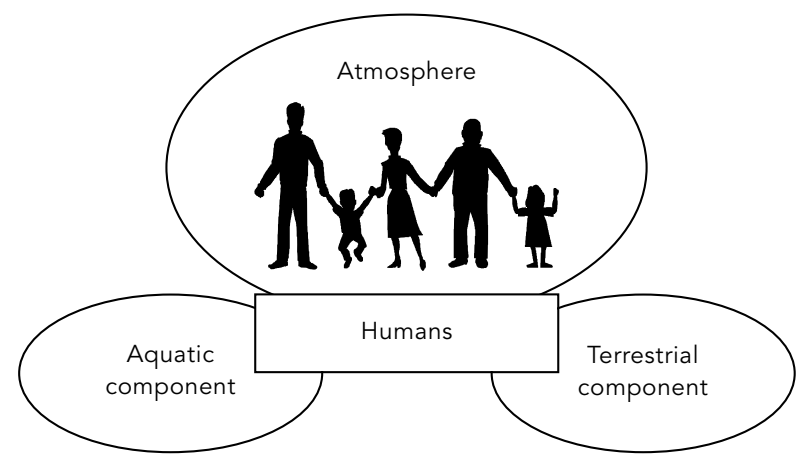

universe is regarded as an ordered entity with a hierarchy of multilevel stratified systems, each higher level being composed of lower levels with additional qualities. The structure and function of each level cannot be reduced to its elementary parts located on the lower level but can be separated into its constituent parts which may operate as quasi-autonomous units (Koestler, 1967; Allan \& Starr, 1982; Naveh \& Liebermann, 1994; Waltner-Toews, this volume). These complex systems may be represented by models, which are not depictions of reality, but abstractions made for specific purposes. Rather than a single all-purpose model, the hierarchical approach entails different theories for different purposes at different scales (Peters, 1991). Models cannot address every aspect of the system, but must be tuned to specific problems (DeAngelis, 1988): a single system is represented by a suite of different models. Integration should not be undertaken by specialists in isolation, but by builder-architects with clear views of overall objectives (Peters, 1991).

Tansley (1935) and Begon et al. (1996), among others, observe that an ecosystem comprises the biological community together with its physical environment. Irrespective of the spatial scale in the definition of the ecosystem, we consider populations as the basic units of communities and rely on demographic principles for the analysis of their spatio-temporal dynamics. Such principles include resourcebased poikilothermic development (e.g. Curry \& Feldman, 1987; Gutierrez, 1996) and the physiological structure of populations (e.g. Di Cola 
et al., 1999). Here, the biological communities, including human populations, interact with factors of the physical environment and are appropriate subsystems for investigation and management. Dealing with people involves ethical considerations. Prudence is called for when applying demographic principles to human population dynamics (Capra, 1997). The definition of subsystems and constituent population is done purposely (Peters, 1991), but further modifications should be considered (Peters, 1991; Gould, 1998). The interactions between the subsystems and their environment determine the structure and function of the system under management.

Kochtcheeva \& Singh (this volume) provide a useful list for the identification of subsystems. Factors of the physical environment, arthropod-transmitted diseases, and resources are regarded as particularly important for human health. Resources refer to everything that permanently reduces in quantity through consumption by an organism (Tilman, 1982; Begon et al., 1996). For people, the initially selected resources are food provided by crops and livestock. Additional resources such as time available for human activities are included as well. The physical environment, arthropodtransmitted diseases, other pests, and limited resources - feed and water for livestock, radiation, water and nutrients for plants - affect the health of crops and livestock. To address local conditions and needs, management procedures need to be developed in close collaboration with the people concerned and implemented within specially designed decisionsupport subsystems.

The human health improvement system comprises 3 sets of subsystems: the disease subsystems (A), the resource subsystems (B), and the decision-support subsystems (C) (Figure 2). In the decision-support subsystems, people interact through exchange of information with people living outside the disease and resource subsystems (A and $B$ ). The mode of interactions between the community and the managed ecosystem facilitates identification of the system's boundary. Once the system and subsystems are defined we can proceed to an outline of important management concepts. Thereby, we use the term "scheme" for an organized control system, which comprises the activities required for managing the systems and subsystems as defined above.

\section{Integrated management of the human health improvement system}

\section{Introduction}

Traditionally, a curative or therapeutic rather than a preventive approach has been used for improving human health. Moreover, different disciplines and institutions have favored a sectorial approach, wherein individual ecological processes and system components received more attention than interactions influencing the functioning and structure of subsystems as well as ecosystems.

The importance of preventive approaches is increasingly being recognized: it has even been acclaimed that the 21 st century must be the one of prevention. Less appreciated is the limited applicability of exclusively curative approaches. They are useful for practitioners, while a combination of curative and preventive approaches can be applied by a wide range of end users including practitioners, extensionists, and policy-makers (Conway, 1984). The curative approach often focuses on individual ecological processes, such as pest mortality, but provides little insight into the dynamics of pest populations, and hence is a hindrance for combining control factors into integrated management schemes (Roux \& Baumgärtner, 1998). Despite the interest in Integrated Pest Management (IPM) (Kogan, 1998), pest control research and practice is still dominated by the quest for a silver bullet (Lewis et al., 1997), i.e., the search for a single factor able to solve a pest problem.

The sectorial approach focusing on individual populations rather than on subsystems and ecosystems is also a hindrance for the design of integrated control programs. For example, Saini et al. (1999a) argued that a comprehensive vector and bovine trypanosomiasis management scheme would be more efficient than uncoordinated reliance on methods for both pathogen and vector control. Furthermore, the villagers involved in the BioVillage project (see below) were not satisfied with a successful tsetse control program but asked for help to control diseases of both humans and livestock and sought assistance in improving food production.

An exclusively curative and sectorial approach precludes consideration of system qualities such as sustainability issues, which are critical to socioeconomic development (Goodland, 1995). The Brundtland Commission defined sustainable development as development that meets the needs of the present with- 
The biotic elements of the human health improvement system (disease subsystems, nutrition-related resource subsystems, and decision-support subsystems).

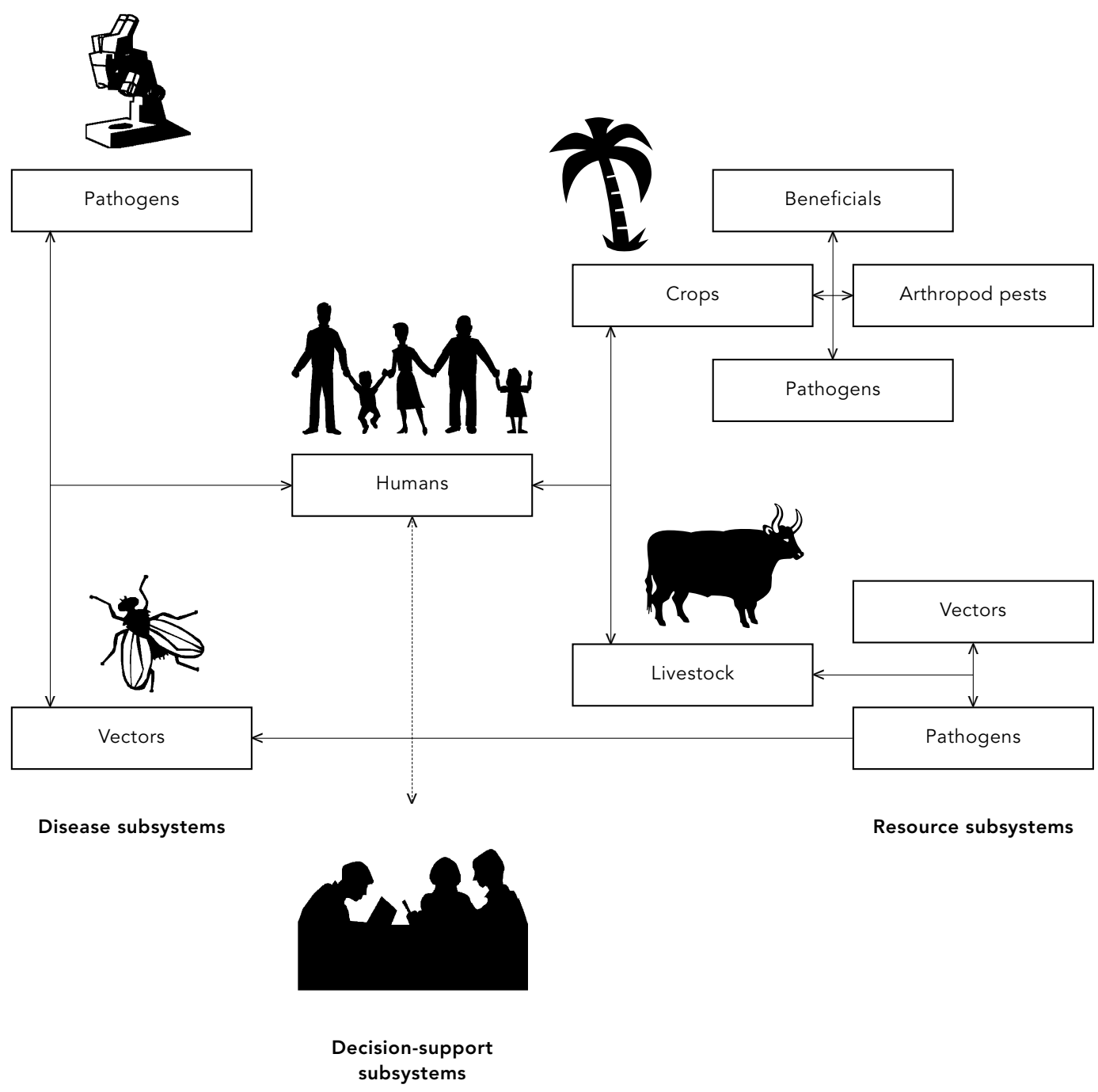

out compromising the ability of future generations to meet their own needs (Eppel, 1999).

In conclusion, an exclusively curative and sectorial approach is too narrow. Integrated comprehensive management schemes, relying primarily on preventive methods, are more promising approaches for further improvements to human health. Moreover, community participation in decision-making processes is fundamental to the development and implementation of management schemes for improving human health.

\section{Management issues}

The objective of improving human health is met by adequately managing both the human disease and the resource subsystems (Figure 2). While the first activity aims at controlling human diseases, the second activity seeks to reduce losses in livestock and crops as well as to manage natural resources to attain environmental sustainability. Goodland (1995) defines environmental, economic, and social sustainability and recognizes the strong link between the first two. He also recognizes the impor- 
tance of social sustainability, but stresses that environmental sustainability or maintenance of life support systems is a prerequisite to social sustainability. Hence, our approach initially focuses on environmental sustainability. Goodland (1995) further reminds us that environmental sustainability requires that the two fundamental environmental services - the source and the sink functions - must be maintained unimpaired during the period in which sustainability is sought.

A decision-support subsystem is indispensable for interactive development and implementation of management schemes (Figure 2). Components of the systems to be managed and management schemes are designed and implemented together with the community through inter-institutional arrangements. The necessary measures may be better implemented when relying on particular segments of the society. There is a special need to focus on women and children. Children, being the parents of the future, need to be involved to facilitate the sustainability of the system. In African society, women are mainly responsible for health and family care, water and fuel collection, and food provision. Their valuable knowledge of the environment and its resources is often underestimated (Wallace, 1991). A detailed analysis of gender roles in a particular cultural context facilitates the design and implementation of an integrated health system for sustainable development.

The design and implementation of management schemes requires initial capital investments, which can be recovered by pricing resources such as water and energy as implementation proceeds. Additional investments into the infrastructure can also be made on a cost-recovery basis.

A comprehensive health and integrated resource management scheme is considered as a prerequisite for undertaking income-generating activities which should be developed on the basis of the available resources (Hufschmidt et al., 1983). For example, we recommend beekeeping and silk production as new sources of income.

\section{Human disease management}

The subjects of management are subsystems including humans, pathogens, and vectors (Figure 2). Disease management aims at reducing morbidity and mortality through the prevention and control of diseases.

\section{Natural resource management}

Management of the resources subsystem focuses on increases in food security - through improved animal and crop agriculture - and sustainable use of natural resources (Figure 3).

The subjects of management are the subsystems including either livestock or crops (Figure 2). Integrated pest management schemes relying on natural control are used for pest control purposes. Environmental sustainability seeks to improve human welfare by protecting the sources of raw materials used for human needs, and by ensuring that the sinks for human wastes are not exceeded, to prevent harm to humans (Goodland, 1995). Moreover, it means that natural capital must be maintained both as a provider of inputs and as a sink for wastes. This means holding the scale of the human economic system within the biophysical limits of the overall ecosystem on which it depends. On the sink side this translates into holding waste emission within the assimilation capacity of the environment without impairing it. On the source side, harvest traits of renewables must be kept within regeneration rate (Goodland, 1995).

To achieve environmental sustainability the flow of water and matter is adequately managed, with the aim of minimizing the necessity for external inputs of resources such as energy and fertilizers and of meeting sanitation requirements. This can be attained through extraction of energy from organic waste and transforming feces or slurry into organic fertilizers by minimizing loss of nutrients such as nitrogen. The soil flora and fauna are indispensable for making nutrients available to crops. High-quality fertilizers are important elements in maintaining sustainable soils (Buol, 1995). They can be produced by separating urine from other organic wastes and processing them further (Bieri et al., 1998). Energy in the form of biogas can be extracted from organic waste for cooking purposes. Furthermore, availability of an alternative resource of energy reduces the workload of women with respect to the collection of, often scarce and heavy, firewood. It may allow women more time for empowering educational and incomegenerating activities. This in turn will benefit human health improvement since it has been shown that education and a better economic position of women contributes to better nutrition and health of the entire family (Østergaard, 1992). The use of biogas rather than firewood is expected to reduce indoor pollution, which causes airborne diseases (WRI, 1998; 
The organization of matter and water flows in a human health improvement system (bold lines: matter including micronutrients, dashed line: water, dotted line: energy).

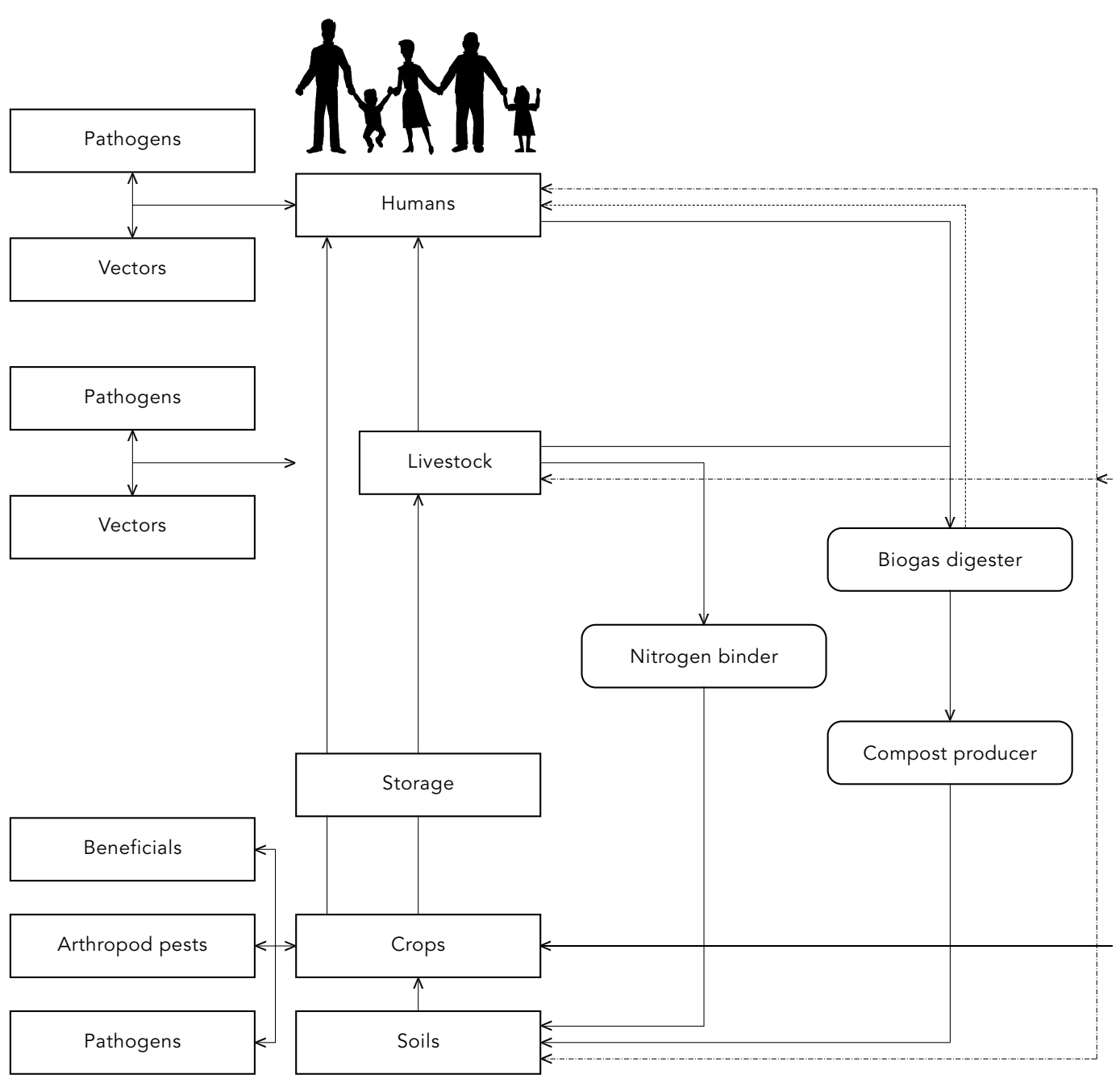

Gopalan \& Saksena, 1999). Note that in this case, environmental sustainability is directly linked to a healthy abiotic human environment.

The management decisions should be based on a quantitative understanding of flows as obtained by the development and use of simulation models.

\section{Decision-support}

Institutional diversity is essential for sustainable systems (Becker \& Ostrom, 1995). Eicher (1999), for instance, recognizes that lack of in- stitutions is a serious hindrance for the implementation of agricultural management schemes in Sub-Saharan Africa. Empowered institutions need to be involved with the development of the decision-support subsystem and play a crucial role in assigning responsibilities in management schemes. The interactions between experts and lay people, mediated through social workers (Figure 2), will benefit the development of improved management procedures whose effects can be monitored (Gopalan, 1999). 


\section{Management scheme implementation}

The concepts proposed above are being implemented with urban (BioFarm Initiative) and rural (BioVillage Initiative) communities in Ethiopia. Preliminary observations show the applicability of the human health systems concepts. This is further supported by the interest of various stakeholders in setting up human health improvement systems in other parts of Ethiopia and in neighboring countries. In this work, we briefly refer to important system components and address some management issues with relevance to the planning of future projects.

\section{BioFarm Initiative}

Recently, one of us (Dr. Getachew Tikubet) designed and implemented a management scheme for improving the health of inhabitants of Addis Ababa. Currently, the scheme focuses on human nutrition. The inhabitants provide the required labor in exchange for food. Livestock is kept under zero grazing conditions to protect them from disease vectors and to control feed supply. Wastes of livestock and the community are processed for energy extraction and organic fertilizer production thereby reducing mosquito and filth fly menace.

\section{BioVillage Initiative}

Historically, the BioVillage Initiative evolved from a successful community-based tsetse control project, which resulted in a significant reduction in livestock disease incidence. Following detailed discussions at the community level, it became apparent that an approach tackling exclusively the trypanosomiasis vector, while desirable, would not fully address the health problems of rural communities. For example, farmers stressed that both oxen and men have to be healthy to plow the fields. It was agreed that only a combined livestock and human health management program could provide a solution to the most urgent problems limiting rural development, and that a comprehensive health management scheme emphasizing preventive rather than curative methods should be initiated. Thereby, it became apparent that health and well-being have to rely on a secured supply of high-quality food and water as well as on a healthy environment. To achieve the latter, efficient waste management with concomitant reduction of disease vector breeding sites became important. These aspects broadened the comprehensive health management concept into an integrated resource management scheme for sustainable rural development. A social worker operating at the interface between community and project management facilitates the exchange of information and manages monitoring work for system evaluation and improvement.

\section{Concluding remarks}

In Sub-Saharan Africa, the physical condition of the human body is primarily affected by abiotic factors, vector-transmitted diseases and natural resources. The ecosystem approach to human health improvement is adequate to identify subsystems for investigation and management in its social context. A preventive integrated management approach for the improvement of human health is suitable for sustainable development.

The human health management scheme aims to control vector-transmitted diseases and secures food supply from resource subsystems including either livestock or crops. Integrated Pest Management relying on natural control factors is the key strategy for reducing losses to biotic constraints, while the concept of environmental sustainability allows adequate management of flows of matter and water. Environmental sustainability is linked to a healthy human environment and is considered as the basis for social and economic sustainability.

A decision-support subsystem is indispensable for planning and implementing management procedures. To achieve sustainability, this subsystem has to be developed together with communities concerned through inter-institutional arrangements. Cost-recovery and resource pricing are important elements for a sustainable management scheme.

Experience from two initiatives in Ethiopia demonstrates the applicability of the concepts to human health improvement in both urban and rural environments. 


\section{Acknowledgments}

The Austrian Development Corporation (ADC) provided the financial support to plan and carry out the BioVillage initiative. We are also grateful to the donors of ICIPE's core funds and to other international partners for financial support. We greatly appreciate the logistic and financial support given by national and regional Ethiopian institutions. The communities of Mamede and Luke in Ethiopia showed us the limitations of the sectorial approach, encouraged us to develop a system approach, and participated in all program activities.

Dr. Hans Herren, Director General of ICIPE, provided continuous support and encouragement. Dr. W. Overholt, Dr. R. Saini, Dr. J. Githure, and Prof. A. Hassanali assisted in project planning and execution. We thank Dr. V. Mares and Dr. H. Li-Pun (ILRI, Addis Ababa) for useful comments and Mrs. Veronica Baumgärtner for assistance with editing of the paper.

\section{References}

ALLAN, T. F. H. \& STARR, T. B., 1982. Hierarchy. Perspectives for Ecological Complexity. Chicago: University of Chicago Press.

BAUMGÄRTNER, J.; DELUCCHI, V.; VON ARX, R. \& RUBLI, D., 1986. Whitefly (Bemisia tabaci Genn., Stern., Aleyrodidae) infestation patterns as influenced by cotton, weather and Heliothis: hypothesis testing by using simulation models. Agriculture, Ecosystems and Environment, 17:49-59.

BAUMGÄRTNER, J.; REGEV, U.; RAHALIVAVOLOLONA, N.; GRAF, B.; ZAHNER, P. \& DELUCCHI, V., 1989. Rice production in Madagascar: Regression analysis with particular reference to pest control. Agriculture, Ecosystems and Environment, 30:37-47.

BEGON, M.; HARPER, J. L. \& TOWNSEND, C. R., 1996. Ecology. 3rd Ed. Oxford: Blackwell Science.

BECKER, C. D. \& OSTROM, E., 1995. Human ecology and resource sustainability: The importance of institutional diversity. Annual Review of Ecology \& Systematics, 26:113-133.

BIERI, M.; KAUFMANN, R.; HELLER, W. \& BERNER, A., 1998. Qualitätsbestimmungen von Schweinemist-Kompost. Agrarforschung, 5:33-36.

BONATO, O.; SCHULTHESS, F. \& BAUMGÄRTNER, J., 1999. Simulation model for maize crop growth based on acquisition and allocation functions for carbohydrate and nitrogen. Ecological Modelling, 124:13-28

BUOL, S. W., 1995. Sustainability of soil use. Annual Review of Ecology \& Systematics, 26:25-44.
CAPRA, F, 1997. The Web of Life. London: Flamingo. CARDWELL, K. F.; SCHULTHESS, F.; NDEMAH, R. \& NGOKO, Z., 1997. A systems approach to assess crop health and maize yield losses due to pest and diseases in Cameroon. Agriculture, Ecosystem and Environment, 65:33-47.

CONWAY, G. R., 1984. Introduction. In: Pest and Pathogen Control. Strategic, Tactical and Policy Models (G. R. Conway, ed.), pp. 1-11, Chichester: John Wiley.

CURRY, G. L. \& FELDMAN, R. M., 1987. Mathematical Foundations of Population Dynamics. College Station: Texas A\&M University Press.

DEANGELIS, D. L., 1988. Strategies and difficulties of applying models to aquatic populations and food webs. Ecological Modelling, 43:57-73.

DI COLA, G.; GILIOLI, G. \& BAUMGÄRTNER, J., 1999. Mathematical models for age-structured population dynamics. In: Ecological Entomology (C. B. Huffaker \& A. P. Gutierrez, eds.), pp. 503-536, 2nd Ed. New York: John Wiley.

EICHER, C. K., 1999. Institutions and the African Farmer. Issues in Agriculture 14. Washington: Consultative Group on International Agricultural Research - CGIAR.

EPPEL, J., 1999. Sustainable development and environment: A renewed effort in the OECD. Environment, Development and Sustainability, 1:41-53.

FITZSIMMONS, A. K., 1999. Ecosystem Health: A flawed basis for government regulation and land management. In: Managing for Ecosystem Health. 
International Congress on Ecosystem Health, $A b$ stracts (The University of California \& the International Society for Ecosystem Health, org.), p. 11, Davis: University of California.

GEBRE AMLAK, A.; SIGVALD, R. \& PETERSON, J., 1989. The relationship between sowing date, infestation and damage by the maize stalk borer, Busseola fusca (Noctuidae), on maize in Awassa, Ethiopia. Tropical Pest Management, 35:143-145.

GOODLAND, R., 1995. The concept of environmental sustainability. Annual Review of Ecology \& Systematics, 26:1-24.

GOPALAN, H. N. B., 1999. Ecosystem health and human well being: The mission of the international programme on plant bioassays. Mutation Research, 426:99-102.

GOPALAN, H. N. B. \& SAKSENA, S., 1999. Domestic Environment and Health of Women and Children. Nairobi: United Nations Environment Program/ Tata Energy Research Institute.

GOULD, S. J., 1998. Leonardo's Mountain of Clams and the Diet of Worms. London: Vintage.

GUTIERREZ, A. P., 1996. Applied Population Ecology: A Supply-Demand Approach. New York: John Wiley.

GUTIERREZ, A. P.; WERMELINGER, B.; SCHULTHESS, F.; BAUMGÄRTNER, J.; YANINEK, J. S.; HERREN, H. R.; NEUENSCHWANDER, P.; LÖHR, B.; HAMMOND, W. N. O. \& ELLIS, C. K., 1988. An overview of a systems model of cassava and cassava pests in Africa. Insect Science and its Application, 8:919924.

HUFSCHMIDT, M. M.; JAMES, D. E.; MEISTER, A. D.; BOWER, B. T. \& DIXON, J. A., 1983. Environment, Natural Systems, and Development: An Economic Valuation Guide. Baltimore/ London: The Johns Hopkins University Press.

KETTLE, D. S., 1995. Medical and Veterinary Entomology. Wallingford: CAB International.

KOESTLER, A., 1967. The Ghost in the Machine. London: Hutchinson.

KOGAN, M., 1998. Integrated pest management: Historical perspectives and contemporary developments. Annual Review of Entomology, 43:243-270.

LAST, J. M. \& ABRAMSON, J. H., 1995. Dictionary of Epidemiology. Oxford: Oxford University Press.

LEWIS, W. J.; VAN LENTEREN, J. C.; PATHAK, S. C. \& TUMLINSON, J. H. III, 1997. A total system approach to sustainable pest management. Proceedings of the National Academy of Sciences, 94: 12243-12248.

MUKHEBI, A. W., 1992. Economic impact of theilerosis and its control in Africa. In: The Epidemiology of Theilerosis in Africa (R. A. I. Norval, B. D. Perry \& A. S. Young, eds.), pp. 379-403, London: Academic Press.

NAVEH, Z. \& LIEBERMANN, A., 1994. Landscape Ecology. Theory and Praxis. 2nd edition, Berlin: Springer.

ØSTERGAARD, L., 1992. Health. In: Gender and Development. A Practical Guide (L. Østergaard, ed.), pp. 110-134, London: Routledge.

PETERS, R. H., 1991. A Critique for Ecology. Cambridge: Cambridge University Press.

ROUX, O. \& BAUMGÄRTNER, J., 1998. Evaluation of mortality factors and risk analysis for the design of an integrated pest management system. Ecological Modelling, 109:61-75.
SAINI, R. K.; BAUMGÄRTNER, J. \& CUISANCE, J., 1999a. In Search of Sustainable Vector Control Systems. Plenary talk presented at the 25th Jubilee Conference of the OAU/ISCTRC, 27 September 1st October, 1999, Mombasa.

SAINI, R. K.; NG'ENY-MENGECH, A. \& OGENDO, I., 1999b. Fighting Africa's Deadly Fly - New Ecofriendly Solutions for Tsetse Management. Accomplishments of the European Union - funded Project on Interactive Development and Application of Sustainable Tsetse Management Technologies for Agropastoral Communities in Africa. Nairobi: International Centre of Insect Physiology and Ecology (ICIPE).

TAMÒ, M. \& BAUMGÄRTNER, J., 1993. Analysis of the cowpea agro-ecosystem in West Africa. I. A demographic model for carbon acquisition and allocation in cowpea, Vigna unguiculata (L.) Walp. Ecological Modelling, 65:95-121.

TAMÒ, M.; BAUMGÄRTNER, J. \& GUTIERREZ, A. P., 1993. Analysis of the cowpea agro-ecosystem in West Africa II. Modelling the interactions between cowpea and the bean flower thrips (Megalurothrips sjostedti (Trynbom) (Thysanoptera, Thripidae)). Ecological Modelling, 70:89-113.

TANSLEY, A. G., 1935. The use and abuse of vegetational concepts and terms. Ecology, 16:284-307.

TILMAN, D., 1982. Resource Competition and Community Structure. Princeton: Princeton University Press.

WALLACE, T., 1991. The Impact of Global Crises on Women. In: Changing Perceptions. Writings on Gender and Development (T. Wallace \& C. March, eds.), pp. 13-68, Oxford: Oxfam.

WHO (World Health Organization), 1995. Vector Control for Malaria and other Mosquito-Borne Diseases. WHO Technical Report Series 857. Geneva: World Health Organization.

WRI (World Resources Institute), 1998. World Resources 1998-99. A Guide to the Global Environment: Environmental Change and Human Health. Oxford: Oxford University Press.

YUDELMAN, M.; RATTA, A. \& NYGAARD, D., 1998. Pest Management and Food Production. Looking to the Future. Food, Agriculture, and the Environment. Discussion Paper 25. Washington, D.C.: International Food Policy Research Institute.

ZAMBESI, B. T. \& MWAMBULA, C., 1996. The impact of drought and low soil nitrogen on maize production in the SADC region. In: Developing Drought- and Low N-tolerant Maize (G. O. Edmeades, M. Baenziger, H. R. Mickleson \& C. B. Pena-Valdivia, eds.), pp.24-29, El Batán: Centro Internacional de Mejoramiento de Maíz y Trigo. 